\title{
Comparing Short-Term Effects of Ammonia and Methylamine on Nitrogenase Activity in Anabaena variabilis (ATCC 29413)
}

\author{
Sabine Reich, Helmar Almon, and Peter Böger \\ Lehrstuhl für Physiologie und Biochemie der Pflanzen, Universität Konstanz, \\ D-7750 Konstanz, Bundesrepublik Deutschland \\ Z. Naturforsch. 42c, 902-906 (1987); received April 13, 1987 \\ Cyanobacterium, Anabaena variabilis, Nitrogenase Regulation, Ammonia, Methylamine \\ Using the heterocystous cyanobacterium Anabaena variabilis (ATCC 29413) in an alkaline \\ environment its nitrogenase activity is rapidly inhibited by ammonia and methylamine. Nitro- \\ genase inhibition by ammonia is probably caused by a mechanism comparable to the switch-off \\ effect, which has been described for several species of the Rhodospirillaceae, whereas methyl- \\ amine-induced inhibition is caused by an uncoupling effect only. Evidence for these different \\ effects is obtained by comparing nitrogenase activity in cell-free extracts of filaments pretreated \\ by ammonia or methylamine. In addition, ammonia-dependent nitrogenase inhibition is shown to \\ be dependent on protein synthesis and on light intensity.
}

\section{Introduction}

As shown previously, nitrogenase activity in intact filaments of Anabaena variabilis is inhibited within minutes by ammonia when cyanobacteria are incubated in an alkaline environment. Alkaline pH-values are necessary to allow for rapid entry of ammonia into the cells by diffusion of the uncharged $\mathrm{NH}_{3}$-molecule [1]. Nitrogenase from ammonia-treated cyanobacteria remained inhibited in cell-free extracts prepared from the organisms [1]. It is assumed that the inhibition of nitrogenase is probably caused by a mechanism similar to the "switch-off" phenomenon, described for several species of the Rhodospirillaceae [2, 3], for which the biochemical mechanism has been shown to be a reversible covalent modification of one Fe-protein subunit of nitrogenase [4-6]. Such a modification has not yet been demonstrated for cyanobacterial nitrogenases, which may be due to the comparatively difficult preparation of the cyanobacterial enzyme. Only partially purified preparations of cyanobacterial nitrogenase or components thereof have been reported $[7,8]$.

Abbreviations: CAP, chloramphenicol; CAPS, 3-cyclohexylamino-propanesulfonic acid; Chl, chlorophyll; CCCP, carbonyl-cyanide- $m$-chlorophenylhydrazone; GOGAT, glutamine-2-oxoglutarate-aminotransferase; HEPES, N-2hydroxyethyl-piperazine-N'-2-ethanesulfonic acid; MSX, L-methionine-D, L,-sulfoximine; TC, tetracycline; TES, Ntris(hydroxymethyl)-methyl-2-aminoethanesulfonic acid.

Verlag der Zeitschrift für Naturforschung, D-7400 Tübingen $0341-0382 / 87 / 0700-0902 \$ 01.30 / 0$
In this paper data are presented characterizing the mode of action of ammonia on nitrogenase activity in cyanobacteria and comparing them with corresponding results reported for the Rhodospirillaceae. As described for the latter species, ammonia switch-off is a reversible process ("switch-on") [2], dependent on the light intensity, because inhibition of nitrogenase by ammonia is more rapid under low light condition [9]. Ammonia, however, is not the direct effector causing nitrogenase switch-off $[1,10-12]$. Apparently, its conversion to glutamine via glutamine synthetase is required, because L-methionine-D, Lsulfoximine, an inhibitor of glutamine synthetase, prevents inactivation caused by ammonia. Besides ammonia, methylamine also induces a fast decrease of nitrogenase activity in intact cells of Rhodopseudomonas capsulata [13]. This methylamine effect has been interpreted as being comparable to the ammonia switch-off.

We studied the short-term effect of methylamine on nitrogenase activity in intact filaments and cellfree extracts of the heterocystous cyanobacterium Anabaena variabilis and compared it with the inhibitory action of ammonia. Furthermore, the influence of light intensity and inhibitors of protein synthesis on ammonia inhibition of nitrogenase was investigated.

\section{Materials and Methods}

Growth of bacteria

Anabaena variabilis (ATCC 29413) was grown under nitrogen-fixing conditions as described previ- 
ously [14]. The inoculation was equivalent to $1.5 \mu \mathrm{g}$ $\mathrm{Chl} \times \mathrm{ml}^{-1}$ and cultures were grown for $24 \mathrm{~h}$ under continuous illumination $\left(200 \mu \mathrm{E} \times \mathrm{m}^{-2} \times \mathrm{s}^{-1}\right)$.

\section{Determination of nitrogenase activity in vivo}

Filaments were harvested by centrifugation ( $5 \mathrm{~min}$ at $2500 \times \mathrm{g}$ ) and resuspended in $20 \mathrm{~mm}$ CAPS, $\mathrm{pH} 10.0$, or in $20 \mathrm{~mm}$ TES, $\mathrm{pH}$ 7.2. The final chlorophyll concentration was $20 \mu \mathrm{g} \mathrm{Chl} \times \mathrm{ml}^{-1} .2 .5 \mathrm{ml}$ of filaments were suspended in glass vials $(25 \mathrm{ml})$ under aerobic conditions in the presence of $11 \% \mathrm{C}_{2} \mathrm{H}_{2}(\mathrm{v} / \mathrm{v})$ and incubated in the light (tungsten lamps) at $30^{\circ} \mathrm{C}$. Acetylene reduction was measured as described previously [15].

\section{Preparation of cell-free extracts}

Filaments were grown and harvested as described above. Subsequently, they were incubated for $20 \mathrm{~min}$ in the light $\left(200 \mu \mathrm{E} \times \mathrm{m}^{-2} \times \mathrm{s}^{-1}\right)$ in the presence or absence of $1.0 \mathrm{~mm}$ methylamine. Following this incubation filaments were concentrated to $300 \mu \mathrm{g} \mathrm{Chl} \times \mathrm{ml}^{-1}$, sparged with argon for $5 \mathrm{~min}$, frozen anaerobically in liquid nitrogen and stored in liquid nitrogen until used. For preparations of cellfree extracts filaments were thawed anaerobically and $2 \mathrm{~mm}$ sodium dithionite was added to the suspension. Cells were broken under continuous sparging with $\mathrm{H}_{2}$ by 2 passages through a French pressure cell (124 MPa).

\section{Determination of nitrogenase activity in vitro}

Cell-free nitrogenase activity was measured with $5 \mathrm{mM} \mathrm{Na}_{2} \mathrm{~S}_{2} \mathrm{O}_{4}$ as electron donor and in the presence of an ATP-regenerating system $(7.5 \mathrm{~mm}$ phosphocreatine, $2.5 \mathrm{~mm}$ ATP, $5 \mathrm{~mm} \quad \mathrm{MgCl}_{2}$ and $0.1 \mathrm{mg} \times \mathrm{ml}^{-1}$ phosphocreatine kinase) in $20 \mathrm{~mm}$ HEPES ( $\mathrm{pH} 7.5$ ). The final volume of the suspension was $0.5 \mathrm{ml}$; cell-free extract was equivalent to $30 \mu \mathrm{g}$ Chl. Reactions were performed in $8 \mathrm{ml}$ vials, closed with rubber stoppers (argon atmosphere $+13 \%$ $\left.\mathrm{C}_{2} \mathrm{H}_{2}, \mathrm{v} / \mathrm{v}\right)$ at $30{ }^{\circ} \mathrm{C}$ in the dark.

\section{Determination of other enzyme activities}

Glutamine synthetase activity was measured at $30{ }^{\circ} \mathrm{C}$ in cell-free extracts using the transferase assay according to [16]. Leucine-dependent transaminase activity was determined according to [17]. The activity of GOGAT was determined under anaerobic con- ditions with reduced methylviologen as electron donor (compare [18]). Glutamate formed was measured by the ninhydrin reaction (A. Wild, personal communication). Cell-free extracts generally were desalted by passage through a Sephadex G 25 column. column.

\section{Chlorophyll determination}

Chlorophyll was determined after methanolic extraction of filaments or by extraction of cell-free extracts with $80 \%$ acetone [19].

\section{Results}

The ammonia switch-off for the Rhodospirillaceae has been described as a reversible process [2]. We therefore tried to assay for reversibility of the ammonia inhibition of nitrogenase in the cyanobacterium Anabaena variabilis under conditions of inhibited protein synthesis. Fig. 1 demonstrates a recovery experiment: Filaments had been incubated for $15 \mathrm{~min}$ in the presence or absence of ammonia. After complete inhibition of nitrogenase activity, filaments were washed and resuspended in a buffer lacking ammonia in the presence or absence of chloramphenicol. Within 25 min after removal of external

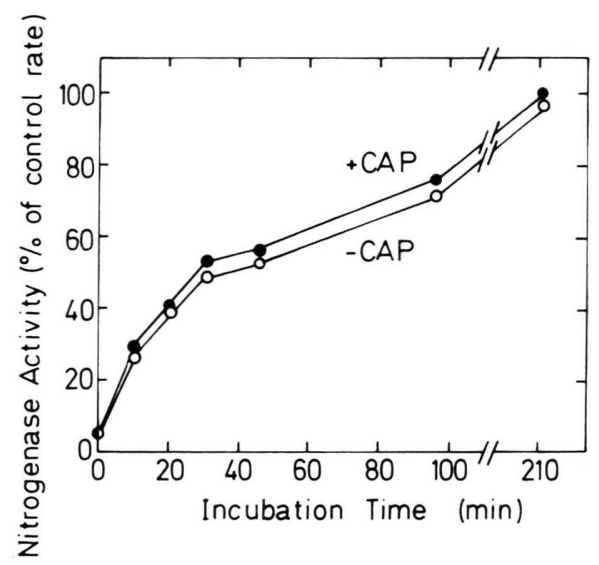

Fig. 1. Reversibility of the ammonia-inhibition of nitrogenase activity of Anabaena variabilis. Intact filaments were incubated in the presence or absence of $1.2 \mathrm{~mm}$ $\mathrm{NH}_{4} \mathrm{Cl} 15 \mathrm{~min}$ in the light $\left(650 \mu \mathrm{E} \times \mathrm{m}^{-2} \times \mathrm{s}^{-1}\right)$ at $\mathrm{pH} 10.0$. Subsequently, filaments were harvested by centrifugation and resuspended in a buffer lacking ammonia in the presence $(-0)$ or absence $(\bigcirc-\bigcirc)$ of $10 \mu \mathrm{g} \times \mathrm{ml}^{-1}$ chloramphenicol $(t=0 \mathrm{~min})$. Control rates $\left(\mu \mathrm{mol} \mathrm{C}_{2} \mathrm{H}_{4} \times \mathrm{mg}\right.$ $\left.\mathrm{Chl}^{-1} \times \mathrm{h}^{-1}\right): 71.2 \pm 15.9$. Data are means \pm standard deviation of at least 6 experiments. 
ammonia, $50 \%$ of the control activity was recovered. The kinetics of reactivation was identical whether filaments were treated with chloramphenicol or not. Reactivation in the presence of chloramphenicol also occurred when cells had been pretreated with chloramphenicol 40 min prior to removal of external ammonia. Chloramphenicol inhibited protein synthesis within $30 \mathrm{~min}$ as shown by a series of experiments, in which nitrogenase had been irreversibly inactivated by oxygen (data not shown).

Noteworthy, chloramphenicol strongly affected the degree of ammonia-induced nitrogenase inhibition. Nitrogenase activity of filaments incubated in the presence of this inhibitor was less sensitive towards ammonia as demonstrated by a time course in Fig. 2. Similar results were obtained when using tetracycline instead of chloramphenicol. Methylamine led to a comparable inhibition of nitrogenase activity as ammonia, but chloramphenicol did not affect the kinetics of methylamine-induced inhibition of nitrogenase (Fig. 2). Enzymic activities of nitrogenase, glutamine synthetase, GOGAT and leucinedependent transaminase as well as the uncoupling effect of ammonia (measured as inhibition of photosynthetic oxygen evolution or respiratory oxygen uptake) were not affected by incubation of filaments for

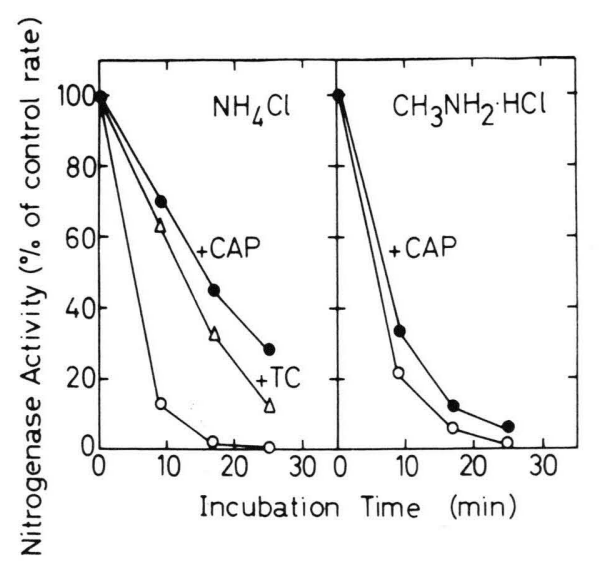

Fig. 2. Effect of chloramphenicol and tetracycline on inhibition of nitrogenase activity caused by ammonia or methylamine in intact filaments of Anabaena variabilis. Filaments were incubated for $20 \mathrm{~min}$ in the light $\left(650 \mu \mathrm{E} \times \mathrm{m}^{-2} \times \mathrm{s}^{-1}\right)$ in the presence of $10 \mu \mathrm{g} \times \mathrm{ml}^{-1}$ chloramphenicol (CAP) $(--), 5 \mu \mathrm{g} \times \mathrm{ml}^{-1}$ tetracycline (TC) $(\triangle \longrightarrow \triangle)$ or in the absence of these inhibitors $(\bigcirc-\bigcirc)$. Subsequently, $1.2 \mathrm{~mm} \mathrm{NH}_{4} \mathrm{Cl}$ or $1.0 \mathrm{~mm} \mathrm{CH}_{3} \mathrm{NH}_{2} \cdot \mathrm{HCl}$ was added $(t=0 \mathrm{~min})$. Control rates $\left(\mu \mathrm{mol} \mathrm{C}_{2} \mathrm{H}_{4} \times \mathrm{mg} \mathrm{Chl}^{-1} \times \mathrm{h}^{-1}\right)$ : $64.6 \pm 10.1$. Data are means \pm standard deviation of $6-12$ experiments.
$25 \mathrm{~min}$ in the presence of chloramphenicol (data not shown).

In addition, the influence of light intensity on inhibition of nitrogenase activity caused by ammonia and methylamine was examined (Fig. 3). With decreasing light intensity, the ammonia concentration had to be increased to attain a comparable degree of nitrogenase inhibition. In contrast, only a marginal effect of light intensity on methylamine-induced inhibition of nitrogenase was observed. When incubated without ammonia or methylamine, light intensity only slightly influenced nitrogenase activity (compare legend to Fig. 3).

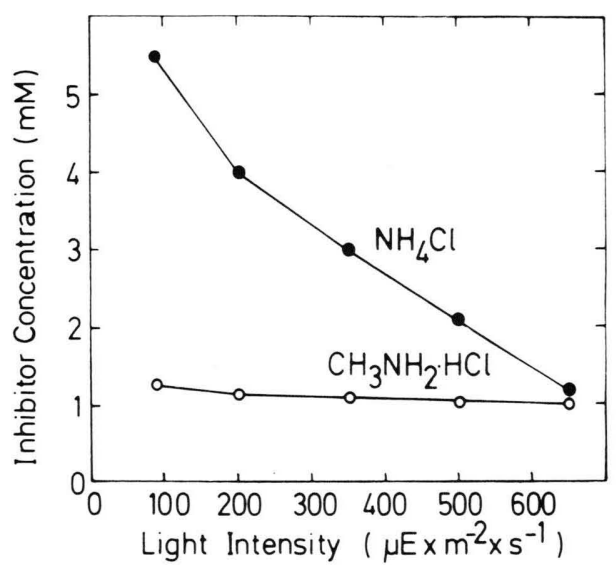

Fig. 3. Effect of light intensity on inhibition of nitrogenase activity caused by ammonia (-) or methylamine $(\mathrm{O}-\mathrm{O})$ in intact filaments of Anabaena variabilis. The inhibitor concentration indicated is the minimum concentration required to reduce nitrogenase activity to less than $10 \%$ of the control rate within $15-20 \mathrm{~min}$. Control rates $\left(\mu \mathrm{mol} \quad \mathrm{C}_{2} \mathrm{H}_{4} \times \mathrm{mg} \quad \mathrm{Chl}^{-1} \times \mathrm{h}^{-1}\right.$ ) varied from 53.8 $\left(90 \mu \mathrm{E} \times \mathrm{m}^{-2} \times \mathrm{s}^{-1}\right)$ to $64.6\left(650 \mu \mathrm{E} \times \mathrm{m}^{-2} \times \mathrm{s}^{-1}\right)$. Data are means of $6-12$ experiments.

As shown previously, inhibition of nitrogenase activity in intact filaments caused by ammonia remained when nitrogenase activity was measured in cell-free extracts prepared from ammonia-treated filaments [1]. In order to compare the effect of methylamine on nitrogenase activity with that of ammonia, cell-free extracts were prepared from intact filaments, which had been incubated with methylamine at $\mathrm{pH} 7.2$ and $\mathrm{pH} 10.0$, respectively (Table I). No effect of methylamine on nitrogenase activity in intact filaments was observed, when cyanobacteria 
Table I. Effect of methylamine on nitrogenase activity of Anabaena variabilis. Intact filaments were incubated for $20 \mathrm{~min}$ in the presence of $1.0 \mathrm{~mm} \mathrm{CH}_{3} \mathrm{NH}_{2} \cdot \mathrm{HCl}$ at $\mathrm{pH} 7.2$ and $\mathrm{pH} 10.0$, respectively. Subsequently, nitrogenase activity was measured using intact filaments or cell-free extracts prepared from these filaments. For experimental details see Materials and Methods. Data are means \pm standard deviation of 6-10 experiments; $n=$ number of cell-free extracts prepared, n. d. = not determined (see ref. [1] for the corresponding ammonia effect).

\begin{tabular}{|c|c|c|c|c|}
\hline \multicolumn{2}{|c|}{ Assay conditions } & \multicolumn{3}{|c|}{$\begin{array}{c}\text { Nitrogenase activity } \\
\left(\mu \mathrm{mol} \mathrm{C}_{2} \mathrm{H}_{4} \times \mathrm{mg} \mathrm{Chl}^{-1} \times \mathrm{h}^{-1}\right)\end{array}$} \\
\hline $\mathrm{pH}$ & Addition & $\begin{array}{l}\text { Intact } \\
\text { filaments }\end{array}$ & $\begin{array}{l}\text { Cell-free } \\
\text { extracts }\end{array}$ & $n$ \\
\hline 7.2 & None (control) & $67.8 \pm 8.5$ & $15.3 \pm 1.1$ & 3 \\
\hline 7.2 & $\mathrm{CH}_{3} \mathrm{NH}_{2} \cdot \mathrm{HCl}(1 \mathrm{~mm})$ & $65.8 \pm 2.0$ & n.d. & 0 \\
\hline 10.0 & None (control) & $65.2 \pm 14.8$ & $15.5 \pm 1.5$ & 3 \\
\hline 10.0 & $\mathrm{CH}_{3} \mathrm{NH}_{2} \cdot \mathrm{HCl}(1 \mathrm{~mm})$ & $4.8 \pm 2.7$ & $13.2 \pm 2.5$ & 4 \\
\hline
\end{tabular}

had been incubated at $\mathrm{pH}$ 7.2. Nitrogenase activity in filaments incubated at $\mathrm{pH} 10.0$, however, was inhibited by methylamine. Although inhibited in vivo, nitrogenase activity in cell-free extracts of methylamine-treated filaments was not markedly altered in comparison to nitrogenase activity in cell-free extracts prepared from untreated filaments (control). Interestingly, the uncoupler CCCP caused an immediate loss of nitrogenase activity in intact filaments which remained persistent in cell-free extracts (data not shown). This effect is not yet understood, a similar phenomenon has been reported for nitrogenase of Rhodospirillum rubrum [20].

\section{Discussion}

Our investigations clearly demonstrate, that ammonia and methylamine inhibit nitrogenase activity in Anabaena variabilis by a different mode of action. Since the inhibition of nitrogenase activity caused by methylamine is not persistent in vitro, we assume that methylamine acts as an uncoupler only. Nitrogenase inhibition by methylamine therefore is overcome in vitro by use of an ATP-regenerating system (compare Table I). Furthermore, light intensity affects inhibition of nitrogenase activity caused by ammonia, a phenomenon not observed when using methylamine. Decreasing light intensities - still not affecting control rates - diminuate the inhibitory effect of ammonia (compare Fig. 3). This suggests, that under conditions of high light intensity ATP and reductant are produced in excess, facilitating the energy-demanding assimilation of ammonia via glutamine synthetase thereby stimulating nitrogenase inactivation. Conversion of ammonia to glutamine had been shown to be essential to cause an ammonia-induced inactivation of nitrogenase which remains persistent in vitro. This inactivation was prevented by MSX, which clearly inhibited glutamine synthetase in Anabaena variabilis [1].

In a series of experiments performed with intact cells of Rhodopseudomonas capsulata methylamine had been reported to inhibit nitrogenase activity by a similar mechanism as ammonia [13]. This conclusion was based on the observation that methylamine was a substrate for glutamine synthetase and that MSX blocked methylamine-induced inhibition of nitrogenase activity. MSX, however, possibly inhibited an ammonia translocator $[21,22]$, catalyzing uptake of methylamine. In addition, methylamine is a very poor substrate for glutamine synthetase in comparison to ammonia: $K_{\mathrm{M}}$ values of $0.89 \mathrm{~mm}$ for ammonia in contrast to $78 \mathrm{~mm}$ for methylamine have been reported for glutamine synthetase from Azotobacter vinelandii [23].

Our results concerning the effect of light intensity on ammonia-induced nitrogenase inhibition are in contrast to experiments described for Rhodospirillum rubrum [9]. In this report the ammonia switchoff was shown to be weakened under conditions of high light intensity, which was interpreted as a decreased production of an effector molecule causing ammonia switch-off. Nevertheless, these data are difficult to compare, because additional factors may be involved in regulation of ammonia-induced nitrogenase inhibition. For Rhodospirillum rubrum and Azotobacter vinelandii parameters like growth conditions in general [24], or the oxygen concentration, $\mathrm{pH}$ and respiratory activity [25] were found to influence ammonia switch-off.

The different mode of action of ammonia and methylamine also becomes evident by the effect of inhibitors of protein synthesis on nitrogenase inhibition. Chloramphenicol and tetracycline only retard the ammonia-induced inhibition of nitrogenase activity (compare Fig. 2). An effect of chloramphenicol on ammonia assimilation by glutamine synthetase and on GOGAT or transaminase activity can be excluded, because these enzyme activities remained unaltered (see above). We therefore assume that the process of ammonia-induced nitrogenase inactivation involves a step requiring protein synthesis. 
In summary, we conclude that methylamine only acts as an uncoupler, whereas ammonia additionally inhibits nitrogenase activity by a switch-off mechanism (compare also [1]). Together with the demonstrated reversibility of the ammonia switch-off effect in Anabaena variabilis, we take this as further evidence for the switch-off/switch-on mechanism of nitrogenase being more widespread among $\mathrm{N}_{2}$-fixing bacteria than hitherto supposed. In fact, it is difficult to assume that such a complicated reaction mechanism (compare [26]) should be restricted to only a few species of nitrogen-fixing organisms. The nitrogenase enzyme is of a rather conservative structure so that regulatory mechanisms which directly involve

[1] S. Reich, H. Almon, and P. Böger, FEMS Microbiol. Lett. 34, 53-56 (1986).

[2] W. G. Zumft and F. Castillo, Arch. Microbiol. 117, 53-60 (1978).

[3] A. H. Neilson and S. Nordlund, J. Gen. Microbiol. 91, 53-62 (1975).

[4] J. W. Gotto and D. C. Yoch, J. Biol. Chem. 257, 2868-2873 (1982).

[5] G. G. Preston and P. W. Ludden, Biochem. J. 205, 489-494 (1982).

[6] M. R. Pope, S. A. Murrell, and P. W. Ludden, Proc. Natl. Acad. Sci. USA 82, 3173-3177 (1985).

[7] P. G. Hallenbeck, P. J. Kostel, and J. R. Benemann, Eur. J. Biochem. 98, 275-284 (1979).

[8] L. B. Tsai and L. E. Mortenson, Biochem. Biophys. Res. Commun. 81, 280-287 (1978).

[9] D. C. Yoch and J. W. Gotto, J. Bacteriol. 151, 800-806 (1982).

[10] D. J. Arp and W. G. Zumft, Arch. Microbiol. 134, 17-22 (1983).

[11] B. L. Jones and K. J. Monty, J. Bacteriol. 139, 1007-1013 (1979).

[12] P. Hillmer and K. Fahlbusch, Arch. Microbiol. 122, 213-218 (1979).

[13] D. C. Yoch, Z. Zhang, and D. L. Claybrook, Arch. Microbiol. 134, 45-48 (1983). subunits of nitrogenase are expected to be operative in principle in any nitrogen-fixing bacterium. Due to different habitats, different energy metabolism and due to species-specific ammonia uptake mechanisms the switch-off effect may be of a minor importance in some bacteria (perhaps including the group of cyanobacteria) whereas it may play a major role in other strains.

\section{Acknowledgement}

This study was supported by the Deutsche Forschungsgemeinschaft (SFB 248), and the "Zentrum für Energieforschung" of this University.

[14] H. Almon and P. Böger, Z. Naturforsch. 39c, 90-92 (1984)

[15] H. Weisshaar and P. Böger, Arch. Microbiol. 136, 270-274 (1983).

[16] B. M. Shapiro and F. R. Stadtman, in: Methods in Enzymology 17 A, 901-922 (1970).

[17] J. M. Romero, E. Flores, and M. G. Guerrero, Arch Microbiol. 142, 1-5 (1985).

[18] T. B. Ray, G. A. Peters, R. E. Toia jr., and B. C. Mayne, Plant Physiol. 62, 463-467 (1978)

[19] G. MacKinney, J. Biol. Chem. 140, 315-332 (1941).

[20] R. H. Kanemoto and P. W. Ludden, J. Bacteriol. 158, $713-720(1984)$.

[21] D. H. Turpin, S. A. Edie, and D. T. Canvin, Plant Physiol. 74, 701-704 (1984).

[22] D. T. Singh, D. R. Modi, and H. N. Singh, FEMS Microbiol. Lett. 37, 95-98 (1986).

[23] E. M. Barnes jr., P. Zimniak, and A. Jayakumar, J. Bacteriol. 156, 752-757 (1983).

[24] W. J. Sweet and R. H. Burris, J. Bacteriol. 145, 824-831 (1981).

[25] J. Klugkist and H. Haaker, J. Bacteriol. 157, 148-151 (1984).

[26] P. M. Vignais, A. Colbeau, J. C. Willison, and Y. Jouanneau, Adv. Microb. Physiol. 26, 155-235 (1985). 